\title{
パターン認識概念に基づく月降水量の解析とシミュレーション ANALYSIS AND SYNTHESIS OF MONTHLY PRECIPITATION DATA BASED ON PATTERN RECOGNITION
}

\author{
宇治橋康行* ・高 瀬 信 忠**・家門 邦 彦*** \\ By Yasuyuki UJIHASHI, Nobutada TAKASE and Kunihiko KAMON
}

\begin{abstract}
A time series of hydrologic data occurs in well defined groups possessing collective properties of the data. Such a collection of properties can be called a hydrologic pattern. The pattern indicates the inter-relationship between adjacent values within the groups i. e. the persistence. A method of streamflow synthesis based on the concept of pattern recognition was first described by Panu et al. The present paper aims at improving Panu's method using the ISODATA algorithm for pattern analysis to adapt to highly variable hydrologic data in Japan. The new model is applied to monthly precipitation data at Kanazawa, Fukui and Toyama in the Hokuriku region.
\end{abstract}

Keywords: time series analysis, data synthesis, pattern recognition, ISODATA

\section{1. まえがき}

水資源システムは，その耐用年数にわたって十分に機 能することが望まれる，したがって，計画・設計に用い られるデータは, 過去の観測データだけでなく将来シス テムが機能する期間内に起こりそうなデータでなければ ならない。このようなデー夕は過去の時系列データの解 析からシミュレーションによって得られる. ThomasFiering の研究以来 ${ }^{1)}$, この分野では多くの研究が行わ れ，種々のモデルが提案され実用に供されてきた.この 間の経緯については, Jackson ${ }^{2)}, P a n u ら^{3)}$ によりレ ビューが行われている.

最近 Panu ら ${ }^{4)}$ は Hurst ${ }^{5)}$ やそれ以前から注目されてい た水文データ中のグループの存在に着目し，グループを 構成するデータの集合的性質を用いてパターン認識概念 に基づくシミュレーションモデルを開発し，カナダの月 流量時系列のシミュレーションを行い, 時系列レベル, 月レベルにおいてシミュレートされたデータは観測デー

* 正会員 工修 金沢大学助手 工学部土木建設工学科 (宁920 金沢市小立野 2-40-20)

** 正会員 工博 金沢大学教授 工学部土木建設工学科 (同上)

*** 工修 (株) 大林組中国電力柳井 LNG タンク JV（研究当 時金沢大学大学院工学研究科学生)
夕のもつ種々の統計量を十分な精度で再現することを報 告している. 彼らの手法は従来の時系列解析にみられな い新しいものであり，その最も大きな特徴は時系列が異 なる確率法則に従う複数の確率過程の合成よりなる母集 団から生成されるとした点にある，すなわち，水文時系 列中に存在する明確なグループ（これを水文パターンと よんだ)，たとえば，高水流量と低水流量あるいは雨期 と乾期はそれぞれ異なる確率法則から生成されると考え た. 彼らのモデルでは, データに対する何の前処理も確 率構造を仮定する必要もない.

本論文では, 変動パターンの複雑なわが国の水文デー タの特性を考慮して, クラスタリングに ISODATA ア ルゴリズムを用いることにより Panuらのモデルを修正 拡張したモデルを提案している.さらに，モデルを北陸 地方の 3 地点の月降水量データに適用し, 降水量の変動 パターンの解析, データシミュレーションを行ったもの である。

\section{2. 水文データ解析とパターン認識}

パターン認識, あるいはその一分野である文字認識, 音声認識，画像認識等に関しては多くの成書がみられる

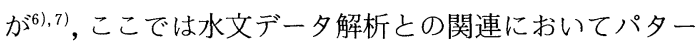
ン認識について概説する ${ }^{8)}$. はじめに基本的な用語の定 


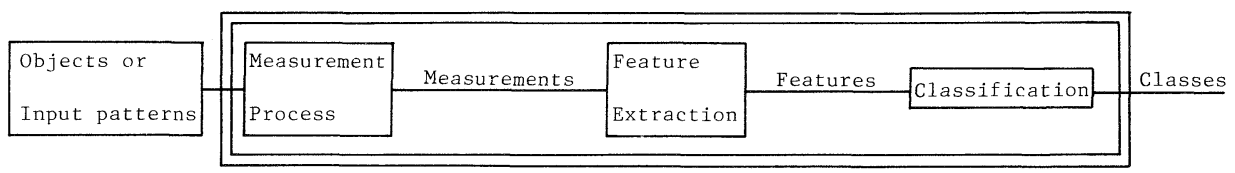

Pattern Recognition System

Fig. 1 Schematic diagram of pattern recognition system.

義について述べる.

パターン認識（pattern recognition）…対象について 観測を行い，さらに，これら観測情報から特徴あるいは 重要な属性を抽出し, 対象を認別可能なクラスに分類す ること.

対象 (object)…われわれが認識分類しようとする物, 物理現象および概念等である. 水文デー夕の解析におい ては与えられた全観測系列が対象となるのではなく 1 年 のあるシーズン（後述の金沢の場合では 1 シーズンの長 さが 3 か月である) に対応する水文時系列の一部.

パターンベクトル (pattern vector)…対象に関して行 われた観測 (measurement) の結果得られた $n$ 個の観 測值の集合からなる $n$ 次元ベクトル $X=\left(X_{1}, X_{2}, \cdots\right.$, $\left.X_{n}\right)$. ここではパターンベクトルを単にパターン (pattern) ともいう. 具体的には, 後述の金沢の月降 水量の例では 1 シーズンが 3 か月であるのでパターンベ クトルは 3 か月の月降水量を要素にもつ三次元ベクト ル，たとえば $X=(247.0,270.0,91.0)$ (各要素の単位 は $\mathrm{mm})$ のようになる.

特徵, 特徵ベクトル (feature, feature vector)…パター ンベクトルは対象に関するすべての情報を含んでおり， この中には認識に無意味な情報も含まれている. 認識に 有効, 必要な重要な情報あるいは属性を特徴とよび, 特 徵を要素にもつ $m$ 次元ベクトル（通常 $m \leqq n ）$ を特徵 ベクトルとよび, パターンベクトルの要素から特徴を抽 出することを特徴抽出 (feature extraction) という.た だし, 本研究の場合では前述のパターンベクトルが必要 なすべての情報を含み，かつ，不必要な情報は含まれて いないのでパターンベクトルを解析の対象とした。

クラス (class)…類似したパターンビうしがつくる集 合. 類似度の尺度としては通常距離を用い, 互いに近い パターンビうしを集めたもの. パターンクラス (pettern class) ともいう. クラスターも同義に用いる.

標準ベクトル (reference vector) …1 つのパターンク ラス内のパターンベクトル（特徵ベクトル）を代表する ようなパターンである. そのパターンクラスに属するパ ターンベクトルの標準ベクトルからの隔たりは標準ベク トルの要素のまわりのパターンベクトルの確率分布によ る. したがって, 標準ベクトルは統計的平均の意味でパ ターンクラス内のパターンを代表する.
パターン認識の一般的な手順は Fig. 1 のように表わさ れよう ${ }^{9)}$.

\section{3. パターン認識概念に基づくモデルの基本構} 成

パターン認識概念に基づく水文データの解析・シミュ レーションモデルは, Fig.2のフローチャートに示され るように，1）パターン解析，2）パ夕ーン構造の統計的 解析，3）データシミュレーションアルゴリズムの 3 つ の要素から構成される.

（1）パターン解析

モデル構成の第 1 段階であるパターン解析は, さらに, パターンベクトルの構成とクラスタリング手順からな る.

a) パターンベクトルの構成 水文データの解析に パターン認識の概念を適用するためには，まず $N$ 年間 の時系列デー夕を対象に分割し，パターンベクトル系列 を得る必要がある. 前述の定義から時系列デー夕の対象 への分割は, 各年を $K$ 個のシーズンに分割することで ある.

Panu ら ${ }^{10)}$ は時系列のシーズンへの分割においてコレ

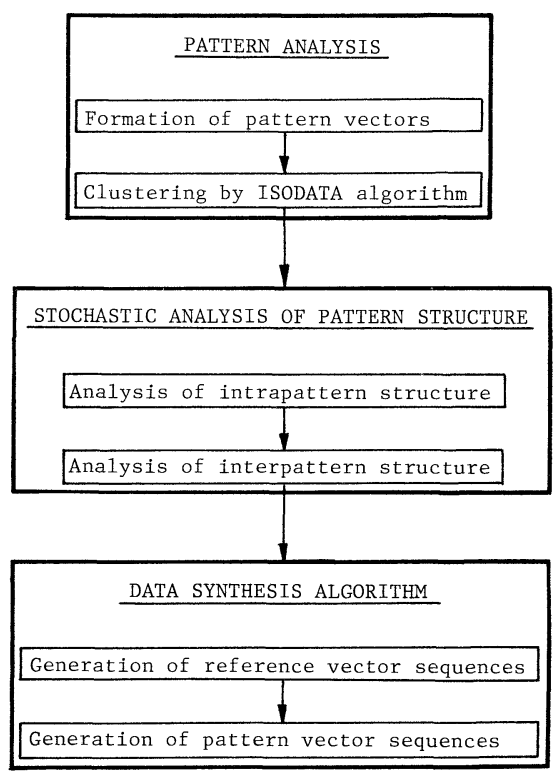

Fig. 2 Flow diagram of model. 
ログラム解析, ペリオドグラム解析によりシーズンの数 と長さを決定し, さらに, ピークー谷解析により各シー ズンの始まりを定めている.ここで, ピーク-谷解析とは, 時系列 $\left\{r_{i}, \quad i=1,2, \cdots, T\right\}$ において,$\quad r_{i-1}<r_{i}>r_{i+1}$ な らばピークの生起, $r_{i-1}>r_{i}<r_{i+1}$ ならば谷の生起, そ れ以外の場合はピーク，谷とも不生起としておのおのの 頻度を求めるものである. 本論文では, 後述のわが国に おける水文デー夕の特性から，さらに，各月の值が年最 大あるいは年最小となる年数, 年平均值以上あるいは以 下となる年数も用いたが，詳細はモデルの適用例におい て述べる.これらの情報に基づいて $N$ 年間の時系列デー 夕は $N \times K$ 個の対象に分割され, 1 シーズン内の $n$ 個 の観測值から形成される $N \times K$ 個の $n$ 次元パターンベ クトルが形成される.

b）クラスタリング Panuらは，シーズンの背後 に存在する物理現象を念頭におき同じシーズンに生起す るパターンは年ごとに異なっているが, これらは同じパ ターンクラスに属するものであると考えた。すなわち， 彼らは時系列を生成する確率法則は各シーズンごとに異 なるが，同一シーズンでは同じであるとした．彼らの対 象としたデータに対して, 最小距離基準と要素誤認基準 を用いることによりほとんど誤認なく，これらのパター ンを認識できることを示している.

Fig. 3 に 1975 年 12 月から 1984 年 11 月までの 10 年 間の金沢の月降水量を示すが，図中には 12 月から 11 月 までを 1 年としたときの各年の最大值および最小值を記 録した月を同時に記入してある。図からわかるように， この 10 年間をみても年最大值，年最小值を記録する月 は毎年同じではなく 7,8 月のように年最大にも年最小 にもなる月もある. また, 1 年の中の変動パターンも年 ごとにかなり異なっているのがわかる. 通常, われわれ が時系列の対象への分割を通じて手にするものは, $n$ 次 元空間の一点としてのパターンである. パターンを数学 的, 統計的に処理する場合, 空間上で互いに近接したパ ターンは, そのパターンを発生させた物理法則が全く異

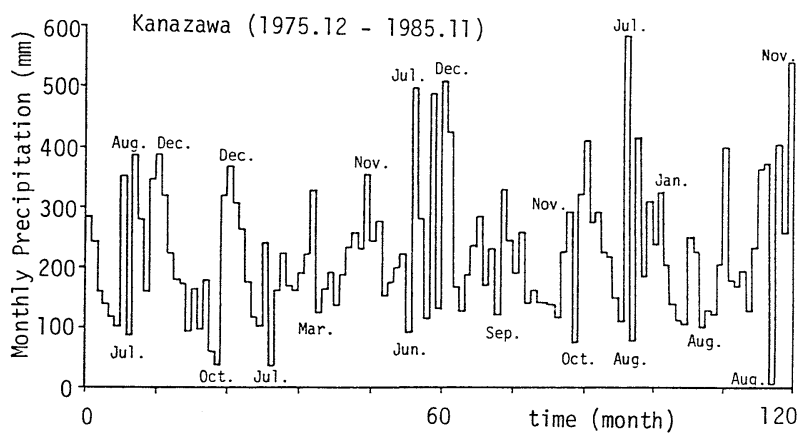

Fig. 3 Monthly precipitation pattern at Kanazawa.
なっていても同一のパターンクラスに属するとみなされ る. したがって, 複雑な変動パターンを示すわが国の水 文デー夕に対しては，同一シーズンに生起するパターン が同一パターンクラスに属すると考えるとPanu らの用 いた分類基準では多数の誤認が生じる.

本研究ではこれらの点を考慮し, シーズンとパターン クラスとの 1 対 1 の対応はないものとし, われわれが手 にしている $N \times K$ 個のパターンから構成されるパター ン空間の構造について, 何の先見的情報ももつていない という立場に立ち，すべてのパターンをISODATA ア ルゴリズムを用いたクラスタリングにより分類した．各 シーズンに各パターンクラスに属するパターンが, ビれ くらい生起したかという分類結果によって各シーズンの 特性および年間の変動パターンについて言及できる。ま たシーズンとパターンクラスが 1 対 1 に対応している場 合には, クラスタリングにより同一シーズンには同じパ ターンクラスに属するパターンのみが生起する結果が得 られるであろう。したがって，シーズンとパターンクラ スの対応については, 本研究での考え方の方がより広い 適用性をもっているものと思われる.

c ) ISODATA アルゴリズム11) ISODATA アル ゴリズムは, Ball and Hall によって考案されたもので, アルゴリズムの一般的な手順は以下のようである.

第 0 ステップ…初期值パラメーターおよび閾值パラ メーターを与える。

第 1 ステップ…与えられた $M_{0}$ 個の初期クラスター中 心に対して，すべての観測パターンをユークリッド距離 を尺度として最も近いクラスター中心に割り当てる.こ の結果, クラスター $C_{j}$ に割り当てられたパターン数が パラメーターク（クラスターを形成するために必要な最 小パターン数）より小さければ，このクラスターは棄て られるが, 残ったクラスターに対して, クラスター内の 平均ベクトル

$$
\boldsymbol{z}_{j}=1 / N_{j} \sum_{i=1}^{N j} \boldsymbol{x}_{i}
$$

を用いてクラスター中心を置き換える.ここに， $N_{j}$ はクラスター $C_{j}$ に属するパターンの数, $\boldsymbol{x}_{i}$ はパターンベクトルである.

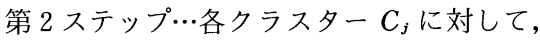
クラスターの中心から各点までの距離の平均 $d_{j}$, 標準偏差ベクトル $\sigma_{j}=\left(\sigma_{1 j}, \sigma_{2 j}, \cdots, \sigma_{n j}\right)$, ク ラスター内の距離 $d_{j}$ の全クラスターにわたる 平均量 $d$ を，それぞれ次式により計算する.

$$
\begin{aligned}
& d_{j}=1 / N_{j} \sum_{i=1}^{N_{j}}\left\|\boldsymbol{x}_{i}-\boldsymbol{z}_{j}\right\| \cdots \cdots \\
& \sigma_{i j}=\left\{1 / N_{j} \sum_{k=1}^{N_{j}}\left(x_{i k}-z_{i j}\right)^{2}\right\}^{1 / 2} .
\end{aligned}
$$




$$
d=1 / M_{m} \sum_{j=1}^{M m} N_{j} d_{j}
$$

ここに, $M_{m}$ は第 $m$ 回目の反復計算で形成されている クラスターの数.

第 3 ステップ…第 3 ステップはクラスターの分割, 結 合である. クラスター $C_{k}$ 内のパターンの各要素の標準 偏差の最大值が与えられたパラメーター $\theta_{s}$ より大きけ れば，その軸に沿ってクラスターを分割する. 2 つク ラスター $C_{k}$ と $C_{l}$ のそれぞれのクラスター中心 $z_{k}$ と $z_{l}$ の間の距離が与えられたパラメーター $\theta_{l}$ より小さけれ ば，これら 2 つのラスターは別個のクラスターとはみ なされず 2 つクラスターを結合する.

第 4 ステップ…最後のステップは, 以上のステップを 与えられた回数 $I_{\max }$ だけ反復することである.

クラスタ一分析の統計的推測の面については, ほとん よ゙何も知られておらず, 指定する必要のある各種パラ メーターの值を選択するために利用できる一般的な指針

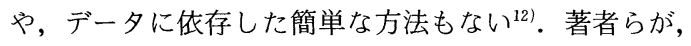
このアルゴリズムを用いた経験では, 初期值パラメー ターの影響は小さく初期クラスター中心の数 $M_{0}=1$, 初 期クラスター中心ベクトル $Z_{0}=(0,0,0)$ を用いれば十分 である.クラスタリングの結果に大きく影響するパラ メータ一は, $\eta, M, \theta_{s}, \theta_{l}$ の 4 つである. 結果として望 むクラスターの数 $M$ については, 指定された $M$ に対 してアルゴリズムの実行結果 $M / 2 \sim 2 M$ 個のクラス ターに分割される. また, 通常パターン空間の構造が不 明であるのでクラスターをいくらにすればよいかも不明 である.したがって $M$ の值としてはおよその上限，下 限のクラスター数から定めればよく, 本研究の場合 $M$ $=5$ とした. $\eta$ はクラスターを形成するのに必要なパ ターン数であり，これを大きくとると棄てられるパター ンが増え, 小さすぎるとパターンクラスの統計的構造の 推定精度が悪くなる.ここでは $\eta=20$ を用いた。 $\theta_{s}$ は 最大標準偏差パラメーターであり，これによりパターン クラス内のパターンのばらつきが制限される， $\theta_{l}$ はパ ターンクラスが別個のパターンクラスとみなされるため に必要なパターン中心間の最小距離であり，ここでは $\theta_{s}$ に対しては与えられたデータの各月の分散の最小值 の $1 / 2, \theta_{l}$ は, 各シーズンに属するすべてのパターンの
平均ベクトルを求め, これらの間の距離の最小值を目安 としてラウンドナンバーを用いた.

本研究で用いたパラメーターの值を Table 1 に示す. 最大反復回数 $I_{\max }=20$ を用いたが, 12 回前後の反復計 算で収束した.

\section{（2）パターン構造の統計的解析}

a) パターン内構造の解析 特定のパターンクラス のパターン内構造 (intrapattern structure) は, クラス ターを構成する各パターンの標準ベクトルのまわりの確 率分布で表わされ，ここでは多変数正規分布を用いる. もし, 第 $j$ パターンクラスに属するパターンの各要素 が多変数正規性を満たさない場合には, 各要素の周辺正 規性を検定し, 正規性を満たさない要素に対して Hinkley 変換 ${ }^{13)}$, Box · Cox 変換 ${ }^{14)}$ 等を行い多変数正規分布 とすればよい. 第 $l$ パターンクラスの多変数正規分布は

$$
\begin{aligned}
p\left(\boldsymbol{x}_{l}\right)= & (2 \pi)^{-n / 2}\left|C_{l}\right|^{1 / 2} \\
& \cdot \exp \left\{-1 / 2\left(\boldsymbol{x}_{l}-\boldsymbol{z}_{l}\right)^{T} C_{l}^{-1}\left(\boldsymbol{x}_{l}-\boldsymbol{z}_{l}\right)\right\}
\end{aligned}
$$

と表わされる.ここに, $x_{l}$ は第 $l$ パターンクラスのパ ターンベクトル， $C_{l}$ は第 $l$ パターンクラスの分散共分 散行列, $z_{l}$ は第 $l$ パターンクラスの標準ベクトルであ るが, 分散共分散行列 $C_{l}$ は, 次式で求められる.

$$
C_{l}=\frac{1}{N_{l}} \sum_{i=1}^{N_{l}} \cdot x_{l i} x_{l i}^{T}-z_{l} z_{l}^{T}
$$

ここに, $x_{l i}$ は第 $l$ パターンクラスの第 $i$ パターンベク トル

b) パターン間構造の解析 パターン間構造（interpattern structure) は, 時系列中の連続するシーズン における標準ベクトルの生起を規定するものである.こ の依存関係は標準ベクトル間の持属性を表わし，ここで は, 一次の Markov 連鎖を用いた. 第 $l$ パターンクラ スから第 $m$ パターンクラスへの遷移確率は, シーズン ごとに異なるので過程は nonhomogeneous である。さ らに, 水文過程の周期性を仮定すれば, 第 $k$ シーズン における標準ベクトル $\boldsymbol{z}_{m}$ の生起確率は, 次式となる.

$$
p\left(\boldsymbol{z}_{k m l}\right)= \begin{cases}p\left(\boldsymbol{z}_{m}(k) \mid \boldsymbol{z}_{l}(k-1)\right), & k \geqq 2, \cdots, K \\ p\left(\boldsymbol{z}_{m}(k) \mid \boldsymbol{z}_{l}(K)\right), & k=1\end{cases}
$$

第 $(k-1)$ シーズンの標準ベクトル $z_{l}$ から第 $k$ シーズン

\begin{tabular}{|c|c|c|c|c|}
\hline \multirow[t]{2}{*}{ Parameter } & \multirow[t]{2}{*}{ Symbol } & \multicolumn{3}{|c|}{ Value } \\
\hline & & Kanazawa & Fukui & Toyama \\
\hline Number of initial cluster centers & $\mathrm{M}_{0}$ & 1 & 1 & 1 \\
\hline Initial cluster center & $\mathrm{Z}_{0}$ & $(0,0,0)$ & $(0,0,0)$ & $(0,0,0)$ \\
\hline Number of clusters desired & M & 5 & 5 & 5 \\
\hline Minimum number of samples desired in a cluster & $\eta$ & 20 & 20 & 20 \\
\hline Maximum standard deviation allowed clusters & $\theta_{\mathrm{s}}$ & 50 & 50 & 50 \\
\hline Minimum distance required between clusters & $\theta_{1}$ & 100 & 70 & 100 \\
\hline Minimum number of paires of clusters that can be Iumped & $\mathrm{L}$ & 1 & 1 & 1 \\
\hline Number of iteration allowed & $I_{\max }$ & 20 & 20 & 20 \\
\hline
\end{tabular}
の標準ベクトル $z_{m}$ への遷移確率は

$$
p_{k l m}=\beta_{l m}(k) / \beta_{l}(k) \text {. }
$$

Table 1 ISODATA argorithm parameters. 
によって求められる.ここに, $\beta_{l m}(k)$ は第 $(k-1)$ シーズ ンにおける第 $l$ パターンクラスに属するパターンベクト ルから第 $k$ シーズンにおける第 $m$ パターンクラスに属 するパターンベクトルへの遷移の観測された総数. $\beta_{l}$ は第 $(k-1)$ シーズンにおける第 $l$ パターンクラスに属 するパターンベクトルの観測総数である.

(3) データシミュレーション

(1), (2) で定められたパターン内およびパターン 間の統計的構造に基ついて，データシミュレーションは 以下のように行われる。その手順は，まず，初期值とし て前シーズンに生起したパターンの属するパターンクラ スを与え，一様乱数を発生させ一次 Markov 遷移行列 に従って各シーズンに生起するベクトルの属するパター ンクラスを定める. 後述の金沢の例のように $8 \supset$ つ゚ ターンクラスに分割されたような場合では, Table 3 の

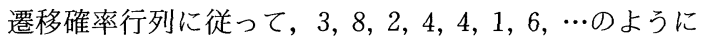
パターンクラスが定められる.これらのパターンクラス に標準ベクトルを対応させることによって標準ベクトル 系列が得られる. 次に, 正規乱数を用い各パターンクラ スの多変数正規分布に従って, 次の最小距離基準を満た すパターンベクトルを発生させ, 標準ベクトル系列をパ ターンベクトル系列に変換する. すなわち, 前ステップ で定められたパターンクラスの標準ベクトルに距離が最 も近いようなパターンベクトルをシミュレートする.

$$
\left\|\boldsymbol{x}_{s}-\boldsymbol{z}_{l}\right\|<\left\|\boldsymbol{x}_{s}-\boldsymbol{z}_{\boldsymbol{j}}\right\|, \quad j=1, \cdots, M ; 1 \neq j \cdots \cdot(9)
$$

ここに， $x_{s}$ はシミュレートされたパターンベクトル， $z_{l}$ は今発生させようとしているパターンベクトルが属 するべきパターンクラスの標準ベクトルである.

\section{4. 実際データへの適用結果と考察}

\section{（1）パターン解析結果}

解析に用いたデー夕は金沢(1886 1986 年, 101 年間), 福井（1897～1984 年，88 年間), 富山（1939 1985 年, 47 年間) の 3 地点における月降水量データである.

Fig. 4, Fig. 5 に各地点のコレログラムおよびペリオドグ ラムをそれぞれ示す。また，Fig. 6 にピーク-谷解析の 結果を, Fig. 7 に年平均値を越える回数 $N_{a}$, 年平均值 以下になる回数 $N_{b}$ を示す. Fig. 4, Fig. 5 にみられる 3 か月周期および Fig. 7 に示されるように $3,4,5$ 月の 3 か月が年平均值以下となる回数が多いことから 3 地点と も 3 か月を 1 シーズンとして 4 シーズンに分割すること とした.

各シーズンの始まりは Fig. 6 のピーク-谷解析の結果 から，各シーズンに大きなピークまたは谷を 1 つずつ含 むようにすることおよび前述の Fig. 7 の結果から第 1 シーズンを $12 \sim 2$ 月, 第 2 シーズンを $3 \sim 5$ 月, 第 3 シー ズンを $6 \sim 8$ 月，第 4 シーズンを $9 \sim 11$ 月とした。この

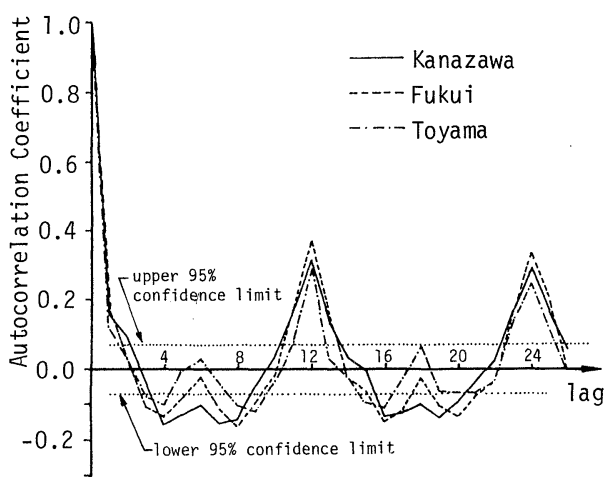

Fig. 4 Correlogram of monthly precipitation.

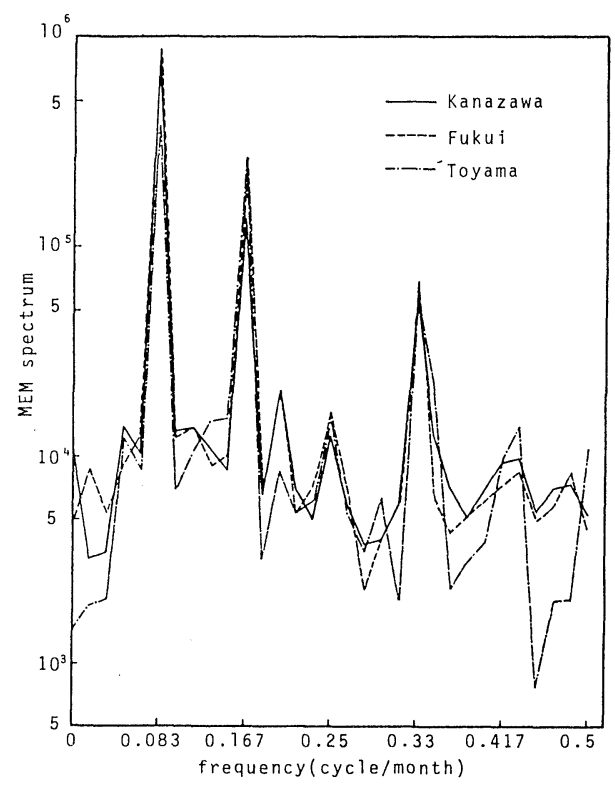

Fig. 5 Periodgram of monthly precipitation.

結果は第 1 シーズンから第 4 シーズンをそれぞれ冬, 春, 夏, 秋亡すれば気象学的季節分けとも一致する. この結 果, 金沢，福井，富山でそれぞれ，400 個，348 個，184 個のパターンが得られる.

Table 1 に示したパラメーターを用いて ISODATA アルゴリズムを実行した結果, 金沢, 福井, 富山でそれ ぞれ 8 個，8個，5 個のパターンクラスに分割された. 得られた標準ベクトルを Fig. 8 に，また，各パターンク ラスに属するパターンベクトルの数とともに Table 2 に 示す. Table 2 にはパターンベクトルの生起数のシミュ レーション結果も合わせて示した. Table 2, Fig. 8 か ら, 北陸地方の降水の変動パターンについて以下のこと がわかる.

(1) 第 1 シーズンでは多降水パターンが全体の約 8 割 を占め, 冬季の降水量が毎年多い. 

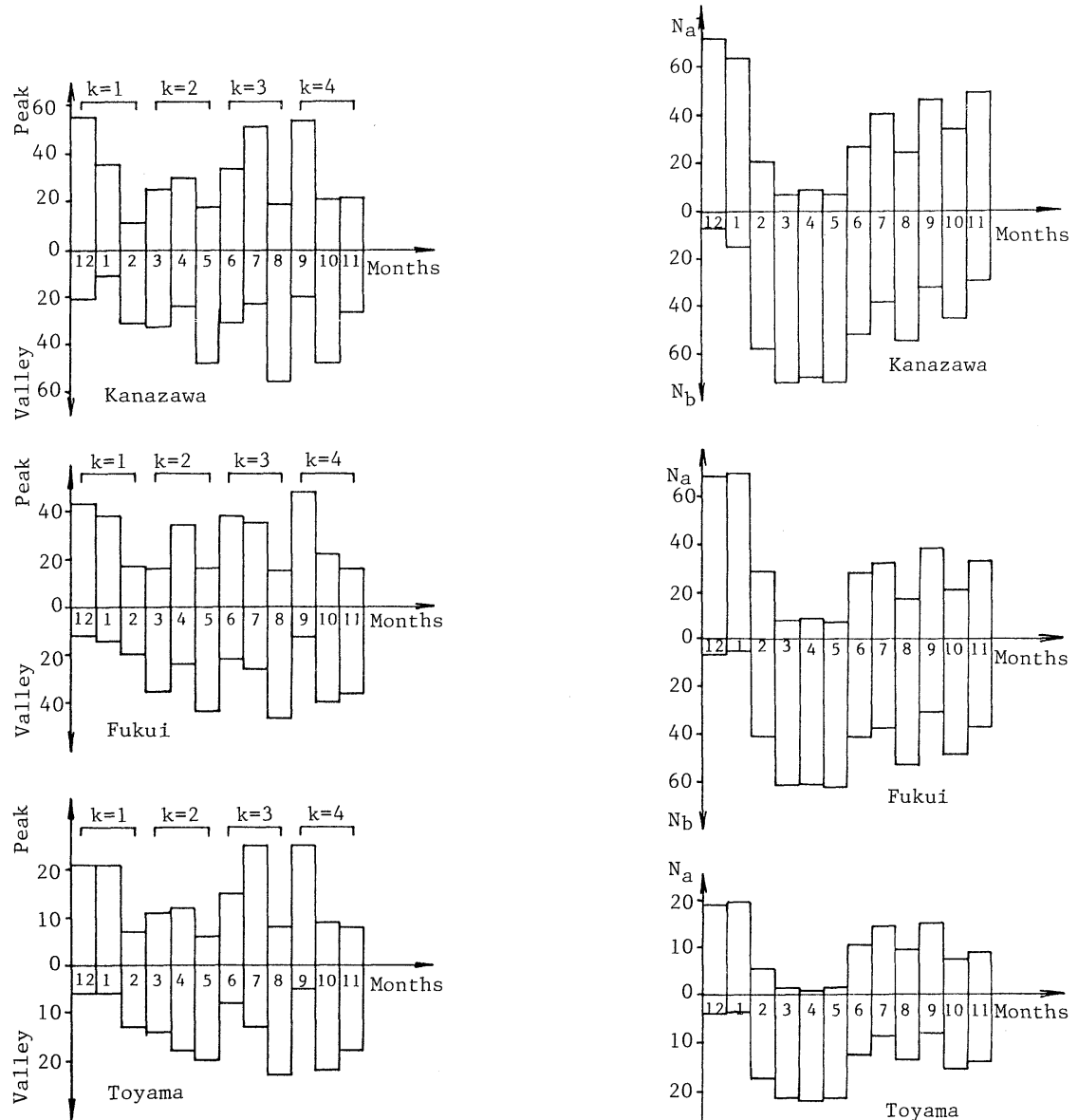

Fig. 6 Peak and valley histogram.

(2) 第 2 シーズンではシーズン中の変動が少なく, し かも少降雨であるパターンが約 7 割を占め年間で最 も降水が少なく経年変動も小さい.

(3) 第 3 シーズンは梅雨を含むシーズンであるが，お よそ 4 年に 1 回は少雨パターンが生起する.また， 梅雨の最盛期はシーズン半ばの 7 月であることがわ かる.

(4) 第 4 シーズンは, 秋雨前線, 台風の有無によって 多くの降水パターンが生じるが，卓越するパターン が 3 つる。

(5) 1 シーズンが 1 パターンクラスに対応するケース はみられないが，各シーズンには 2 4 個の卓越す る変動パターンが存在する.

3 地点の合計 21 個のパターンクラスについて Kolmogorov-Smirnov 検定を行った結果，各パターンクラス に属するパターンベクトルの要素の標準ベクトルのまわ りの多変数分布は有意水準 $5 \%$ で多変数正規分布であ るとみなされた。また，各パターン間の共分散行列を求
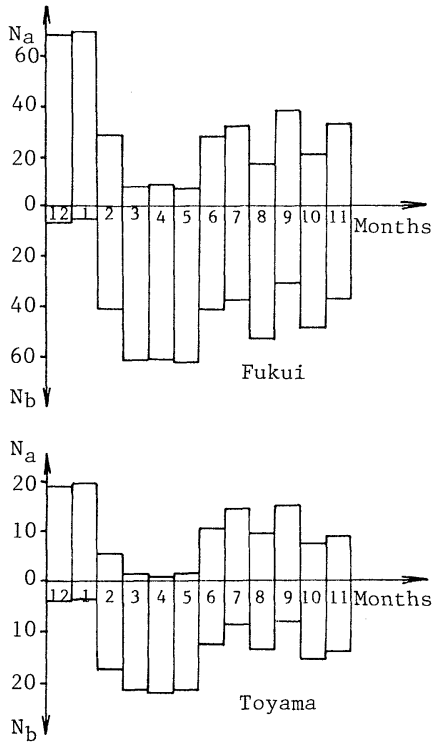

Fig. 7 Histogram of $N_{a}$ and $N_{b}$.

めたところこれら行列の共分散要素は十分小さく，各パ ターンクラスは互いに独立であるとみなせた．Table 3 に各地点の遷移確率行列を示す。

(2) シミュレーション

シミュレーションは，データ年数と同じ年数のシミュ レーションをそれぞれ 30 回行った. 年時系列レベルで のシミュレーション結果を Table 4 に示す. Table 4 よ り, 3 地点の観測值の統計量は金沢, 福井の尖度, 富山 の Hurst 係数を除いてすべてシミュレーションデータの $95 \%$ 信頼限界内に入っており年時系列レベルでの再現 性は良好であるといえる。また，Table 2 に示されるよ うに各シーズンのパターンベクトルの生起数も十分再現 されている．月レベルでの結果をFig.9，10 に示す．図 より金沢，富山での 3,8 月の分散を除いて他のすべて の月の平均，分散ともシミュレーションデータの $95 \%$ 信頼限界内にあり，月レベルにおいてもデー夕の再現性 は良好であるといえる.Fig. 11 にはコレログラムを示 すが，この図から各地点とも観測地はシミュレーション 

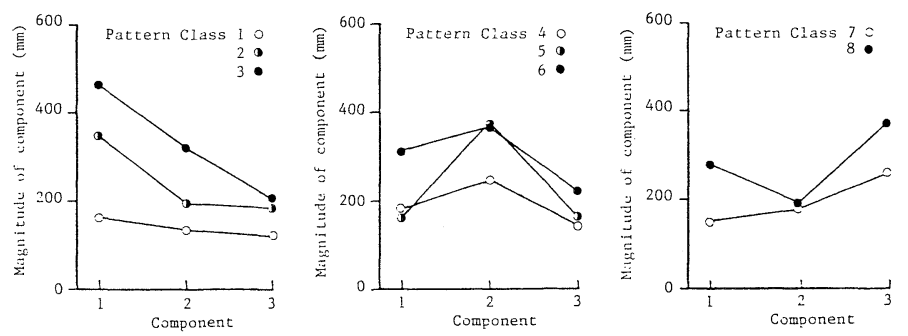

(a) Kanazawa
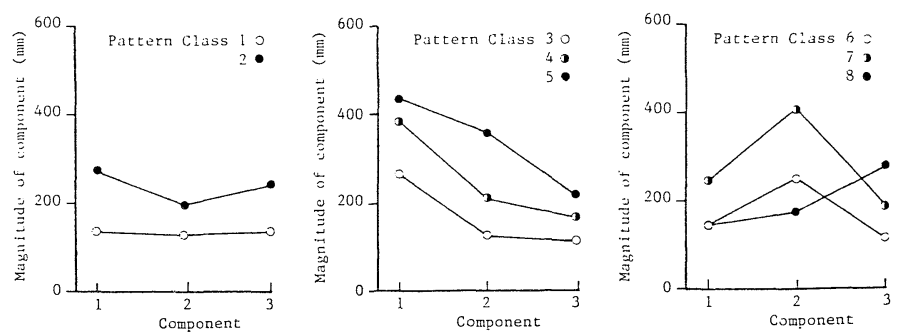

(b) Fukui
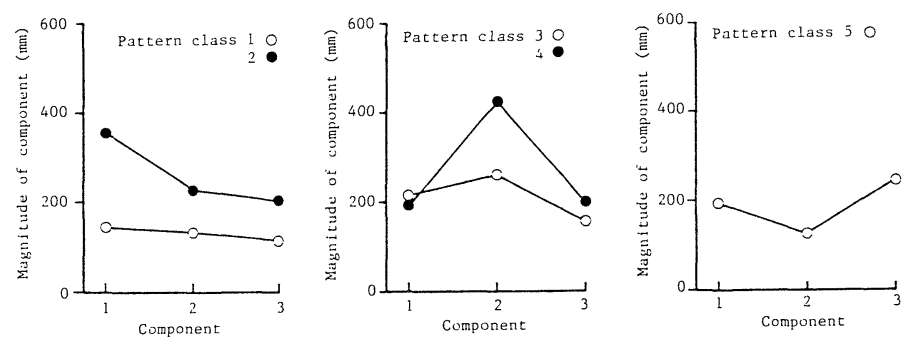

(c) Toyama

Fig. 8 Reference vectors.

Table 2 Summary of intrapattern structures.

\begin{tabular}{|c|c|c|c|c|c|c|c|c|c|c|c|c|c|c|}
\hline \multirow{3}{*}{$\begin{array}{l}\text { Pattern } \\
\text { Class }\end{array}$} & \multicolumn{6}{|c|}{ Reference vector } & \multicolumn{8}{|c|}{ Occurence times of pattern vectors at each season } \\
\hline & \multicolumn{3}{|c|}{ Component } & \multicolumn{3}{|c|}{ Standard deviation } & \multicolumn{4}{|c|}{ Historical data } & \multicolumn{4}{|c|}{ Synthetic sequences } \\
\hline & 1 & 2 & 3 & 1 & 2 & 3 & 1 & 2 & 3 & 4 & 1 & 2 & 3 & 4 \\
\hline 1 & 164.5 & 136.6 & 121.7 & 43.1 & 43.2 & 42.0 & 1 & 67 & 28 & 14 & $1.0(1.0)$ & $67.3(5.4)$ & $27.9(3.4)$ & $12.9(3.3)$ \\
\hline 2 & 347.3 & 197.1 & 183 & & & & 32 & 2 & 5 & 21 & 31.3 & $2.0(1.6)$ & $5.5(2.5)$ & $20.9(4.2)$ \\
\hline 3 & 463.0 & 322.1 & 204.4 & 60.7 & 74.0 & 74.1 & 25 & 0 & 1 & 2 & $25.3(4.8)$ & $0(0)$ & $0.9(1.0)$ & $1.7(1.4)$ \\
\hline 4 & 184.0 & 247.8 & 140.0 & 43.4 & 26. & 39. & 12 & 14 & 17 & 5 & $11.6(2.8)$ & $13.9(3.0)$ & $16.8(2.8)$ & $5.0(2.6)$ \\
\hline 5 & 162.4 & 372.9 & 163.3 & 71.7 & 88.0 & 79.3 & 6 & 1 & 23 & 7 & $5.3(1.7)$ & $0.6(1.0)$ & $22.7(4.7)$ & $7.4(2.6)$ \\
\hline 6 & 311.3 & 365.8 & 218.4 & 40.6 & 86.2 & 67.0 & 22 & 0 & 3 & 7 & $22.5(3.7)$ & $0(0)$ & $2.8(1.8)$ & $8.0(3.2)$ \\
\hline 7 & 280.6 & 191.5 & 367.6 & 68.2 & 57.8 & 48.1 & 1 & 0 & 6 & 23 & $1.1(0.9)$ & $0(0)$ & $5.4(2.1)$ & $22.0(4.3)$ \\
\hline 8 & 148.7 & 175.9 & 255.7 & 45.3 & 57.8 & 48.1 & 1 & 16 & 17 & 21 & $0.8(0.8)$ & $15.2(3.7)$ & $17.0(4.4)$ & $21.0(3.8)$ \\
\hline
\end{tabular}

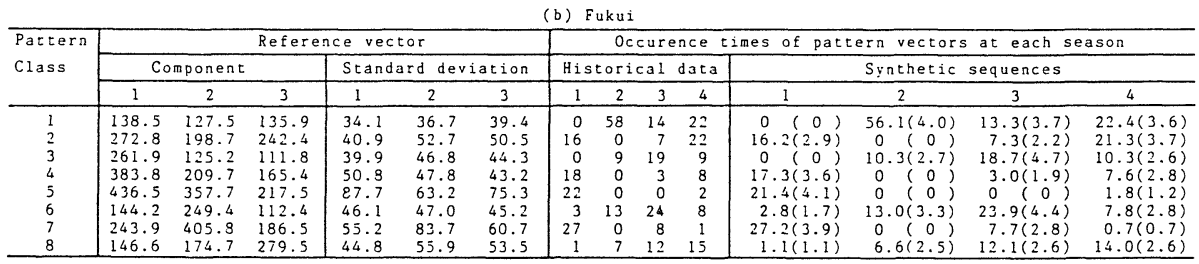

(c) Toyama

\begin{tabular}{|c|c|c|c|c|c|c|c|c|c|c|c|c|c|c|}
\hline \multirow{3}{*}{$\begin{array}{l}\text { Pattern } \\
\text { Class }\end{array}$} & \multicolumn{6}{|c|}{ Reference vector } & \multicolumn{8}{|c|}{ Occurence times of pattern vectors at each season } \\
\hline & \multicolumn{3}{|c|}{ Component } & \multicolumn{3}{|c|}{ Standard deviation } & \multicolumn{4}{|c|}{ Historical data } & \multicolumn{4}{|c|}{ Synthetic sequences } \\
\hline & 1 & 2 & 3 & 1 & 2 & 3 & 1 & 2 & 3 & 4 & 1 & 2 & 3 & 4 \\
\hline $\begin{array}{l}1 \\
2 \\
3 \\
4 \\
5\end{array}$ & $\begin{array}{l}146.6 \\
356.6 \\
213.1 \\
192.1 \\
193.6\end{array}$ & $\begin{array}{l}132.4 \\
228.4 \\
260.1 \\
423.8 \\
125.8\end{array}$ & $\begin{array}{l}115.4 \\
203.3 \\
153.5 \\
198.7 \\
248.7\end{array}$ & $\begin{array}{l}43.0 \\
54.3 \\
53.3 \\
77.7 \\
56.4\end{array}$ & $\begin{array}{l}44.6 \\
72.6 \\
47.1 \\
90.3 \\
45.9\end{array}$ & $\begin{array}{l}35.4 \\
59.2 \\
48.9 \\
86.8 \\
63.8\end{array}$ & $\begin{array}{r}2 \\
18 \\
16 \\
8 \\
2\end{array}$ & $\begin{array}{r}40 \\
0 \\
0 \\
0 \\
6\end{array}$ & $\begin{array}{r}12 \\
3 \\
10 \\
12 \\
9\end{array}$ & $\begin{array}{r}12 \\
14 \\
10 \\
1 \\
9\end{array}$ & $\begin{array}{r}2.2(1.4) \\
17.3(4.0) \\
16.6(2.8) \\
7.4(2.7) \\
1.5(1.1)\end{array}$ & $\begin{array}{c}38.5(2.7) \\
0 \quad(0) \\
0 \quad(0) \\
0(0) \\
6.5(2.7)\end{array}$ & $\begin{array}{r}11.7(3.4) \\
2.9(1.6) \\
9.0(2.8) \\
12.9(3.1) \\
8.4(2.5)\end{array}$ & $\begin{array}{r}11.0(3.1) \\
14.2(2.7) \\
9.6(2.9) \\
0.6(0.9) \\
9.5(3.2)\end{array}$ \\
\hline
\end{tabular}


Table 3 First order transition matrices.

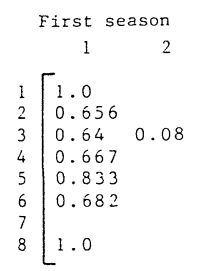

0.0310 .157 0.08

0.166

0.167

0.182

(a)Kanazawa

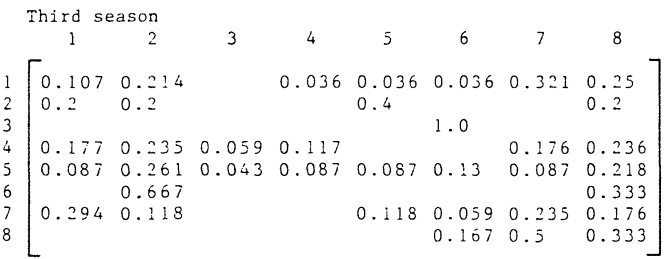

\section{Second season}

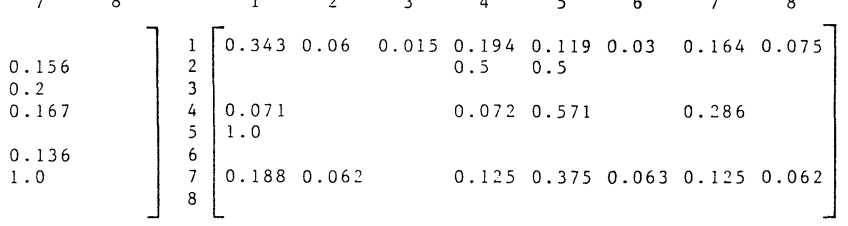

Forth season

\begin{tabular}{|c|c|c|c|c|c|c|c|c|}
\hline & 1 & 2 & 3 & 4 & 5 & 6 & 7 & 8 \\
\hline 1 & 0.286 & & 0.286 & 0.143 & 0.143 & 0.142 & & \\
\hline 2 & & 0.333 & 0.143 & 0.143 & 0.047 & 0.286 & & 0.048 \\
\hline 3 & & & 0.5 & & 0.5 & & & \\
\hline 4 & & 0.2 & 0.4 & 0.4 & & & & \\
\hline 5 & & 0.143 & 0.286 & 0.143 & 0.143 & 0.285 & & \\
\hline 6 & & 0.429 & 0.286 & & & 0.285 & & \\
\hline 7 & & 0.381 & 0.238 & & 0.048 & 0.333 & & \\
\hline 8 & 0.044 & 0.347 & 0.261 & 0.174 & & 0.131 & 0.043 & \\
\hline
\end{tabular}

(b) Fukui
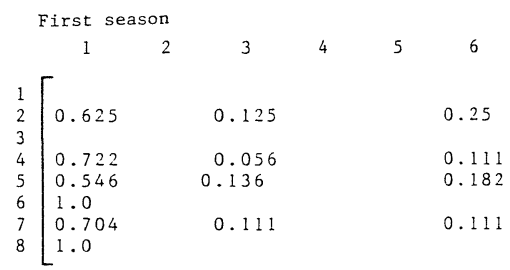

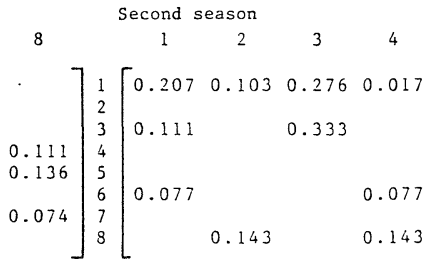
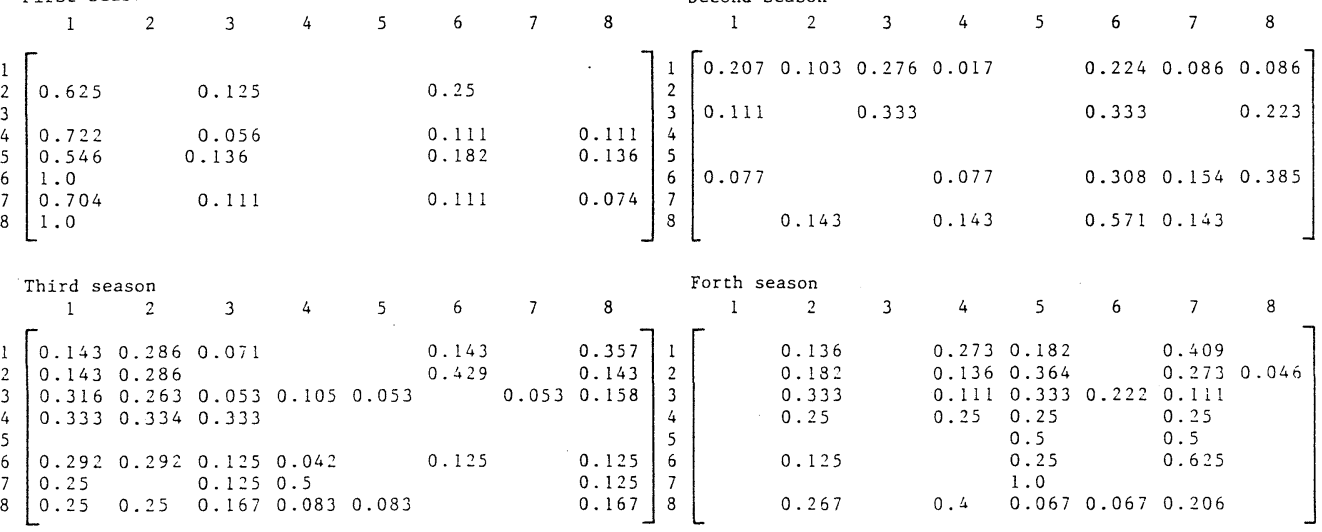

Forth season

\section{(c) Toyama}

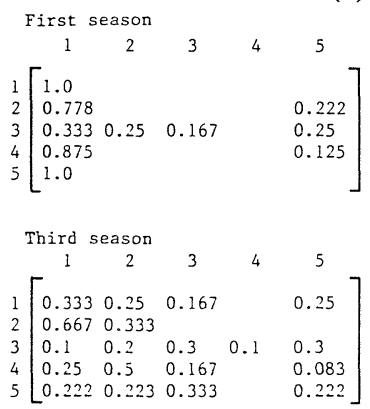

データの $95 \%$ 信頼限界内にあることがわかる.

以上の結果から, 本モデルによりデータのもつ種々の 統計量, 平均, 分散, ひずみ度, Hurst 係数のほか, 自 己相関構造も十分再現されておりシミュレーションモデ ルとして十分であることが示された.

\section{5. 結語}

本研究で得られた結果を要約すると次のようである.

（1）コレログラム, ペリオドグラム, ピーク-谷解

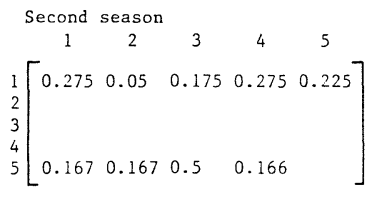

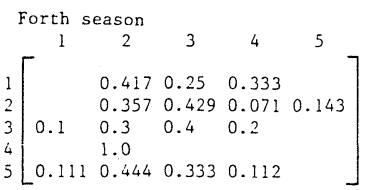

析および年平均以上，あるいは以下となる年数に基づく シーズン分割結果は通常の季節と一致した。

（2）ISODATA アルゴリズムを用いたパターン解 析の結果, シーズンとパターンクラスには 1 対 1 の対応 はないが, 各シーズンには卓越する 3,4 個のパターン が存在し，このパターンによりシーズンおよび年間の降 水特性を明らかにすることができた。

（3）パターン内およびパターン間の統計構造に基づ く本モデルによるシミュレーション結果は年時系列レベ 
Table 4 Comparison of statistics from annual historical and synthetic sequences.

\begin{tabular}{l|lll|lll|ll|r}
\hline & \multicolumn{3}{|c|}{ Kanazawa } & \multicolumn{3}{c|}{ Fukui } & \multicolumn{3}{c}{ Toyama } \\
\cline { 2 - 10 } & Mean & S.D. & H.D. & Mean & S.D. & H.D. & Mean & S.D. & H.D. \\
\hline Mean & 215.3 & 3.15 & 214.0 & 201.8 & 2.56 & 201.2 & 196.5 & 3.60 & 195.8 \\
S.D. & 105.9 & 2.43 & 102.5 & 102.8 & 2.41 & 99.5 & 98.3 & 3.18 & 95.4 \\
lag 1 A.C. & 0.163 & 0.029 & 0.161 & 0.181 & 0.023 & 0.170 & 0.105 & 0.042 & 0.117 \\
Skewness & 0.927 & 0.073 & 1.010 & 1.041 & 0.046 & 1.068 & 1.047 & 0.109 & 1.070 \\
Kurtosis & 3.553 & 0.257 & 4.429 & 3.935 & 0.208 & 4.465 & 3.987 & 0.386 & 4.700 \\
Hurst Co. & 0.524 & 0.008 & 0.525 & 0.520 & 0.006 & 0.526 & 0.527 & 0.008 & 0.601 \\
\hline
\end{tabular}

H. D. : Historical data

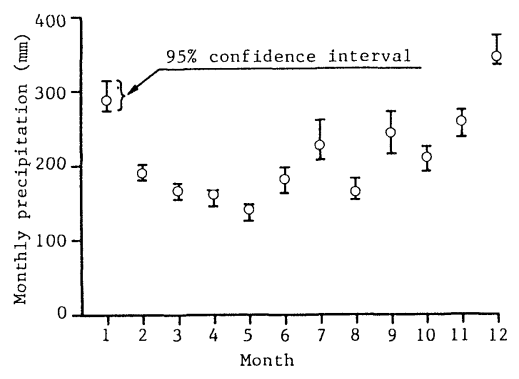

(a) Kanazawa

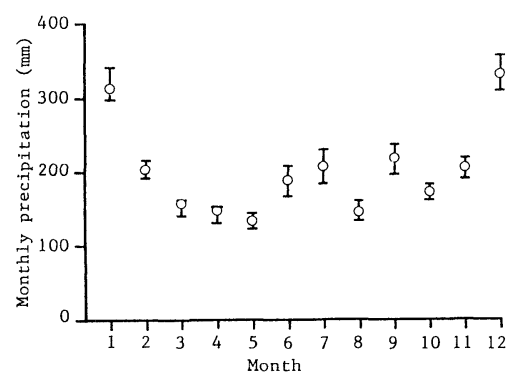

(b) Fukui

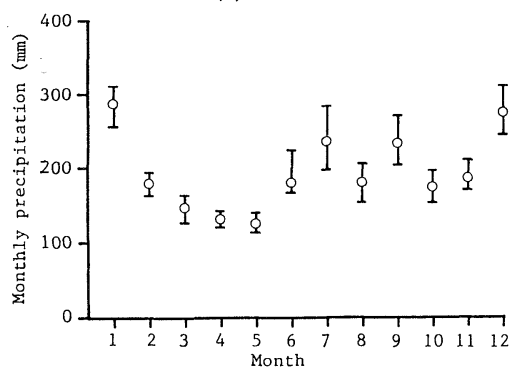

(c) Toyama

Fig. 9 Comparison of monthly means for historical monthly precipitation and $95 \%$ confidence interval for 30 synthetic sequences.

ル，月レベルの両方で良好であった.

ここでは水文時系列の変動パターンの解析とデータシ ミュレーションのみを扱ったが，本モデルは水文パタ一 ンの確率評価や予測問題への適用も可能である.さらに, 水文データのパターン分類の考えは，一雨降雨のような

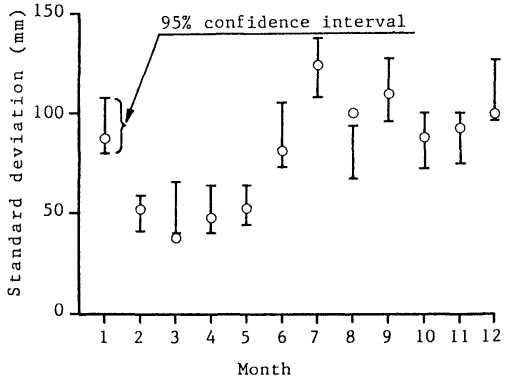

(a) Kanazawa

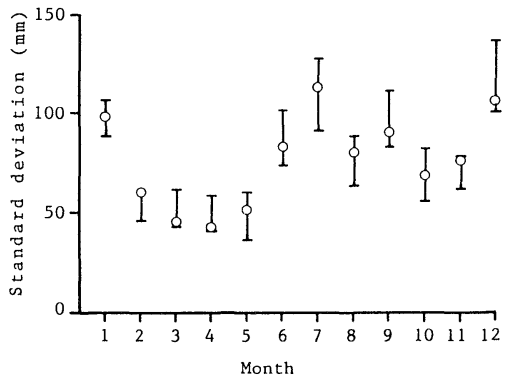

(b) Fukui

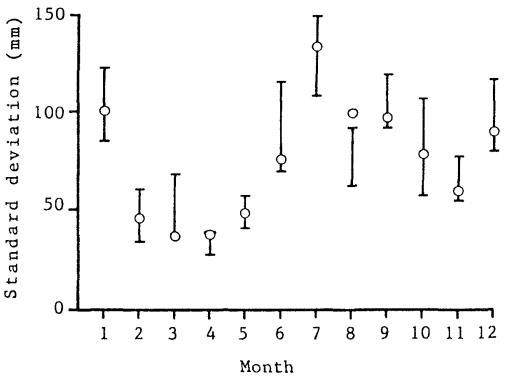

(c) Toyama

Fig. 10 Comparison of monthly standard deviation for historical monthly precipitation and $95 \%$ confidence interval for 30 synthetic sequences.

短時間系列の時空間的変動パターンの解析にも適用でき よう.

最後に本研究をまとめるにあたって適切な助言を頂い た山梨大学 竹内邦良教授に感謝の意を表します. 


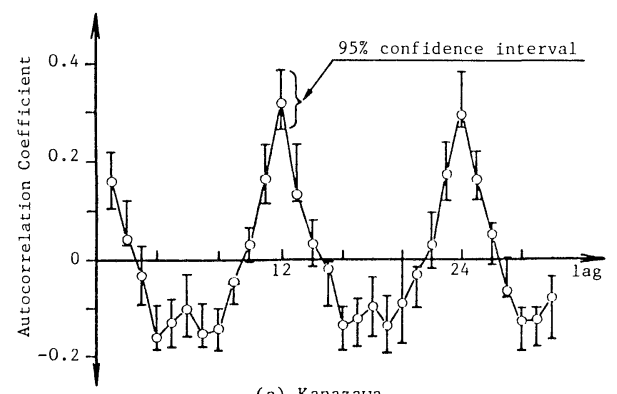

(a) Kanazawa
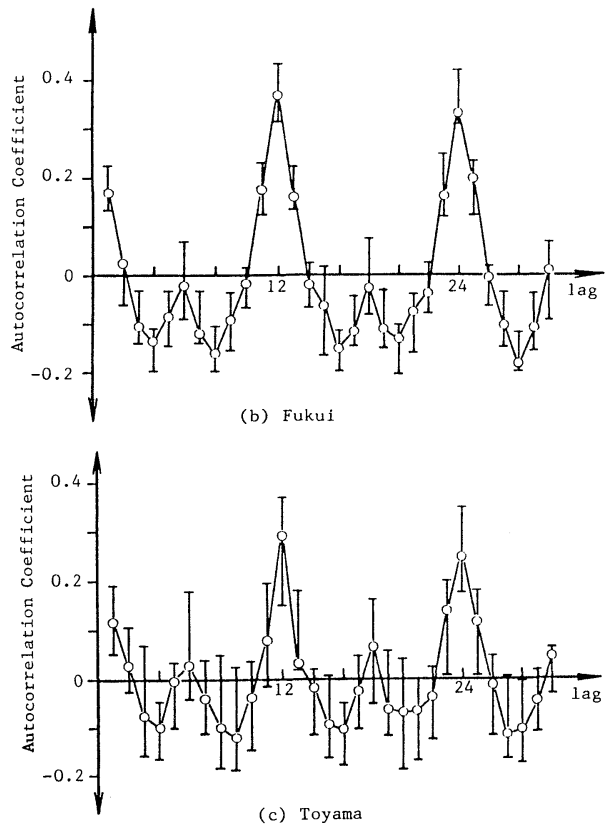

Fig. 11 Comparison of correlogram for historical monthly precipitation and $95 \%$ confidence interval for 30 synthetic sequence.

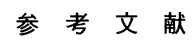

1) Thomas, H.A. and Fiering, M. B. : Mathematical synthesis of streamflow sequences for the analysis of river basins by simulation, in Design of Water Resources Systems, edited by A. Mass et al., Harvard University Press, 1962.

2) Jackson, B. B. : The use of streamflow models in planning, Water Resources Research, Vol.11, No.1, pp. 54 $\sim 63,1975$.

3) Panu, U. S. and Unny, T. E. : Stochastic synthesis of hydrologic data based on concepts of pattern recognition I, Journal of Hydrology, Vol.46, pp.5 34, 1980.

4) Panu, U.S. and Unny, T.E. : A feature prediction model in synthetic hydrology based on pattern recognition, Water Resources Research Vol. 14, No. 2, pp. 335 $\sim 344,1978$.

5) Hurst, H. E. : Long-term storage capacity of reservoirs, Transaciton of American Society of Civil Engineering, Vol. 16, pp. 770 808, 1951.

6) Tou, J. T. and Gonzelez, R. C. : Pattern recognition principles, Addison-Wesley, 1974.

7) 坂井利之編：パターン認識の理論, 共立出版, 1967.

8) Panu, U.S. and Unny, T.E. : Entropy concept in feature extraction and hydrologic time series synthesis, in Modeling Hydrologic Processes, edited by Morel, H. J. et al., Water Resources Publications, 1979.

9) Laveen, K. : Pattern in pattern recognition : 1968 1974, IEEE Transactions on information theory, Vol. IT-20, No. 6, pp. 697 722, 1974.

10) Panu, U.S. and Unny, T.E. : Stochastic synthesis of hydrologic data based on concepts of pattern recognition II, Journal of Hydrology, Vol.46, pp.197 217, 1980.

11）たとえば，前出 6).

12) Gnanadesikan, R. : Methods for statistical data analysis of multivariate observations, John Wiley \& Sons, 1977.

13) Hinkley, D. V. : On quick choice of power transformation, Applied Statistics, Vol. 26( 1 ), pp. 67 69, 1977.

14) Box, G. E. P. and Cox, D. R. : An analysis of transformations, Journal of Royal Society, Service B, Vol.26, pp. 211 252, 1946.

(1988.12.1 • 受付) 